\title{
In situ hybridization for the detection of rust fungi in paraffin embedded plant tissue sections
}

\author{
Mitchell A. Ellison', Michael B. McMahon², Morris R. Bonde², Cristi L. Palmer ${ }^{3}$ and Douglas G. Luster ${ }^{2 *}$ (D)
}

\begin{abstract}
Background: Rust fungi are obligate pathogens with multiple life stages often including different spore types and multiple plant hosts. While individual rust pathogens are often associated with specific plants, a wide range of plant species are infected with rust fungi. To study the interactions between these important pathogenic fungi and their host plants, one must be able to differentiate fungal tissue from plant tissue. This can be accomplished using the In situ hybridization (ISH) protocol described here.

Results: To validate reproducibility using the ISH protocol, samples of Chrysanthemum $\times$ morifolium infected with Puccinia horiana, Gladiolus $\times$ hortulanus infected with Uromyces transversalis and Glycine max infected with Phakopsora pachyrhizi were tested alongside uninfected leaf tissue samples. The results of these tests show that this technique clearly distinguishes between rust pathogens and their respective host plant tissues.

Conclusions: This ISH protocol is applicable to rust fungi and potentially other plant pathogenic fungi as well. It has been shown here that this protocol can be applied to pathogens from different genera of rust fungi with no background staining of plant tissue. We encourage the use of this protocol for the study of plant pathogenic fungi in paraffin embedded sections of host plant tissue.
\end{abstract}

Keywords: Basidiomycota, Pucciniomycotina, Rust fungus, In situ hybridization, Puccinia horiana, Uromyces transversalis, Phakopsora pachyrhizi, Chrysanthemum x morifolium, Gladiolus × hortulanus, Glycine max

\section{Background}

Rust fungi (Basidiomycota, Pucciniomycotina) are obligate parasites that infect many species of vascular plants $[1,2]$. Recent studies in this laboratory have focused on Chrysanthemum white rust, caused by Puccinia horiana, Gladiolus rust, caused by Uromyces transversalis and Asian soybean rust, caused by Phakopsora pachyrhizi. $[3,4]$. Studies on the interactions between these pathogenic fungi and plants would benefit from approaches that allow visualization of the pathogen within host plant tissue, including the use of in situ hybridization (ISH) technology.

\footnotetext{
*Correspondence: doug.luster@ars.usda.gov

2 USDA-ARS Foreign Disease-Weed Science Research Unit, Ft. Detrick, MD, USA

Full list of author information is available at the end of the article
}

ISH was first used to localize specific DNA sequences on chromosomes using probes labeled with radioisotopes $[5,6]$. The technique was later used for the detection of viral particles and high copy number mRNA in cultured cells and sectioned tissue making it useful for localizing gene expression patterns [6-10]. Non-radioactive methods were also developed that employed digoxygenin or biotin-conjugated nucleotides allowing for detection with antibody and streptavidin conjugates [9-11]. The development of non-radioactive methods eventually gave rise to fluorescent ISH (FISH), which employs various fluorescent-labeling techniques to produce fluorescence at the site of hybridization [12-14]. Non-radioactive ISH methods have been used to accomplish such tasks as chromosome mapping [14-16], gene expression localization $[6,8,9,11]$, and pathogen detection [17-26]. Chromogenic ISH (CISH) is an alternative to FISH that 
has become popular in diagnostic laboratories studying human pathogens [19-24].

Recently ISH has been used to identify microorganisms by targeting rRNA [18, 21, 24, 27-32]. The abundance of rRNA in the cell offers ample target for probes to bind to allowing for clear visualization of microorganisms within the sample being assayed. This technique has been used to identify and characterize prokaryotic organisms [27, $29,32]$ and has been used for the detection of fungi in cultures $[24,31]$, plant $[17,18,20,30]$ and animal tissue $[19,21-23,25]$.

The aim of this study was to develop a basic ISH protocol that plant pathologists can use for the detection of rust pathogens in paraffin embedded plant tissue. Here we report the development of an optimized protocol tested on three genera of rust fungi from three plant species. The results of this investigation demonstrate the utility of ISH as a tool for visualizing the infection of plant tissue by rust fungi.

\section{Methods}

\section{Generation of infected leaf material}

Leaves of Chrysanthemum $\times$ morifolium infected with Puccinia horiana isolate PA-11 [33], Gladiolus $\times$ hortulanus infected with Uromyces transversalis isolate CA-07 [34], and Glycine max infected with Phakopsora pachyrhizi isolate Taiwan 72-1 [35] were generated for experiments as described. These plant pathogens are regulated under the Plant Protection Act of 2000 and inoculations were conducted in a BSL-3 Plant Pathogen Containment Facility at Ft. Detrick MD under conditions specified in valid USDA APHIS PPQ 526 permits.

\section{DNA extraction and sequencing for ISH probe design}

Genomic DNA was extracted from $50 \mathrm{mg}$ of fungal basidiospores of Puccinia horiana using a hexadecyltrimethylammonium bromide (CTAB) extraction protocol beginning with $1 \mathrm{~min}$ of homogenization in 500 $\mu \mathrm{L}$ of CTAB extraction buffer $(1 \%$ CTAB, $0.7 \mathrm{M} \mathrm{NaCl}$, $100 \mathrm{mM}$ Tris (pH 7.5), $10 \mathrm{mM}$ EDTA, $0.3 \mathrm{mg} / \mathrm{mL}$ proteinase $\mathrm{K})$. Homogenized samples were incubated at $65{ }^{\circ} \mathrm{C}$ for $30 \mathrm{~min}$, placed on ice for $2 \mathrm{~min}$, and extracted with $500 \mu \mathrm{L}$ of chloroform: isoamyl alcohol (24:1) by $10 \mathrm{~s}$ of vortexing followed by centrifugation at $14,000 \times g$ for $10 \mathrm{~min}$. A volume of $300 \mu \mathrm{L}$ of aqueous phase liquid was collected from each sample, combined with an equal volume of CTAB extraction buffer, re-extracted with $500 \mu \mathrm{L}$ of chloroform: isoamyl alcohol (24:1), vortexed, and centrifuged at $14,000 \times g$ for $10 \mathrm{~min}$. An equal volume of isopropanol was added to $400 \mu \mathrm{L}$ of aqueous phase extract, which was gently mixed, and centrifuged at $14,000 \times g$ for
15 min. Following removal of isopropanol, DNA pellets were washed with $500 \mu \mathrm{L}$ of $70 \%$ ethanol, and centrifuged at $14,000 \times g$ for $20 \mathrm{~min}$ at $4{ }^{\circ} \mathrm{C}$. Once $70 \%$ ethanol was removed and nucleic acid pellets were allowed to dry a volume of $50 \mu \mathrm{L}$ of TE buffer (10 mM Tris, $\mathrm{pH}$ 8.0, $1 \mathrm{mM}$ EDTA) containing $1 \mathrm{mg} / \mathrm{mL}$ RNase A was added to each sample. Final concentrations of extracted DNA were determined using a Nanodrop 2000 (Thermo Fisher Scientific Inc, Waltham, MA).

Basidiospore DNA was amplified using primers for $18 \mathrm{~S}$ rDNA (Table 2) in conventional PCR reactions and products were verified by gel electrophoresis. Post-amplification products were purified using ExoSAP-IT reagent (USB Corporation) before sequencing with BigDye Terminator version 3.1 cycle sequencing kit (ABI, Foster, $\mathrm{CA}$ ). BigDye reaction products were purified using a DyeEx $^{\circledR}$ 2.0 Spin Kit (Qiagen), and analyzed on an ABI 3130XL sequencer (Applied Biosystems).

\section{Tissue sample collection and fixation}

Rectangular leaf tissue samples measuring $4 \mathrm{~cm}$ by $1 \mathrm{~cm}$ were cut from infected leaves using a sterile razor blade and placed into a $50 \mathrm{~mL}$ conical tube containing $30 \mathrm{~mL}$ of FAE fixative ( $2 \%$ formaldehyde, $5 \%$ acetic acid, $60 \%$ ethanol) (see supplementary protocol). After $48 \mathrm{~h}$ of incubation at $4{ }^{\circ} \mathrm{C}$ FAE fixative was removed from the sample tubes and samples were washed with $70 \%$ ethanol for $5 \mathrm{~min}$ before incubation at room temperature in $70 \%$ ethanol for one week. After fixation in FAE fixative and clearing in $70 \%$ ethanol samples were shipped to American Histolabs (Rockville, MD) for RNase-free preparation, including paraffin embedding, sectioning, mounting on positively charged microscope slides, and deparaffinization. All microscope slide samples were stored at $-80^{\circ} \mathrm{C}$ prior to pre-hybridization.

\section{Prehybridization}

All steps listed in the pre-hybridization protocol were carried out under ribonuclease (RNase) free conditions (see supplementary protocol). Slide mounted tissue samples were rehydrated by incubation in $100 \%$ ethanol, $50 \%$ ethanol, and diethylpyrocarbonate (DEPC)-treated water for 3 min each. Following rehydration samples were treated with $0.2 \mathrm{M} \mathrm{HCl}$ for $20 \mathrm{~min}$, washed for $2 \mathrm{~min}$ in DEPCtreated water, and incubated at $70{ }^{\circ} \mathrm{C}$ for $20 \mathrm{~min}$ in $2 \times$ SSPE $\left(0.3 \mathrm{M} \mathrm{NaCl}, 2 \mathrm{mM}\right.$ EDTA, $20 \mathrm{mM} \mathrm{NaH}{ }_{2} \mathrm{PO}_{4}, \mathrm{pH}$ 7.4 ), before digestion with $10 \mathrm{ug} / \mathrm{mL}$ proteinase $\mathrm{K}$ in proteinase $\mathrm{K}$ buffer $\left(20 \mathrm{mM}\right.$ Tris- $\mathrm{HCl}$, pH 7.0, $2 \mathrm{mM} \mathrm{CaCl}_{2}$ ). Digestion was stopped by washing with $2 \times$ SSPE for $5 \mathrm{~min}$ at room temperature, and tissue was treated with $0.1 \mathrm{M}$ TEA (0.1 M triethanolamine- $\mathrm{Cl}, \mathrm{pH}$ 8.0) containing 
$0.5 \%$ acetic anhydride (Sigma, St. Louis, MO) (v/v) for 10 min preceding treatment with biotin and streptavidin blocking solutions. Blocking of endogenous biotin is achieved by treating samples with $1 \mathrm{~mL}$ of $1 \times$ Blocking Reagent (Roche, Indianapolis, IN) containing 4 drops $/ \mathrm{mL}$ of streptavidin blocker (Vector Laboratories, Burlingame, CA) for $15 \mathrm{~min}$, and washing for $5 \mathrm{~min}$ in $2 \times$ SSPE before applying $1 \mathrm{~mL}$ of $1 \times$ Blocking Reagent containing 4 drops/ $\mathrm{mL}$ of biotin blocker (Vector Laboratories, Burlingame, CA) for $15 \mathrm{~min}$. After blocking, slides were washed in $2 \times$ SSPE for $5 \mathrm{~min}$ and dehydrated by incubation with DEPCtreated water, $50 \%$ ethanol, and $100 \%$ ethanol consecutively for $3 \mathrm{~min}$ each. Samples were allowed to air dry while hybridization mixture was prepared.

\section{Hybridization}

Hybridization mixture $(0.3 \mathrm{M} \mathrm{NaCl}, 20 \mathrm{mM}$ Tris $(\mathrm{pH}$ 7.5), EDTA $2 \mathrm{mM}, 500 \mu \mathrm{g} / \mathrm{mL}$ tRNA, $500 \mu \mathrm{g} / \mathrm{mL}$ poly(A) RNA, $1 \times$ Denhardt's Solution [36], $10 \%$ deionized formamide, $9 \mathrm{ng} / \mu \mathrm{L}$ DNA probe) was prepared and heated to $85-95{ }^{\circ} \mathrm{C}$ for $2 \mathrm{~min}$ before being placed into ice for $2 \mathrm{~min}$. After the hybridization mixture was prepared, a volume of $100 \mu \mathrm{L}$ was added to each sample slide, a coverslip was applied, and sample slides were placed into a plastic container lined with paper towels moistened with 4X SSPE. Sample slides were incubated overnight at $42{ }^{\circ} \mathrm{C}$ in one pint polypropylene snap-lid plastic containers in a H9270 Dual-Chamber Hybridization Oven (Thermo Fisher Scientific, Waltham, MA).

\section{Post hybridization, staining, and permanent mounting}

Slides were removed from the $42{ }^{\circ} \mathrm{C}$ hybridization oven and dipped in $2 \times$ SSPE to aid in coverslip removal. Once coverslips were removed slides were washed in $2 \times$ SSPE for $30 \mathrm{~min}$ at room temperature, $1 \times$ SSPE for $30 \mathrm{~min}$ at $52{ }^{\circ} \mathrm{C}$, and blocked for $30 \mathrm{~min}$ at room temperature using $1 \times$ Blocking Reagent. Samples were treated with Streptavidin-HRP at a concentration of 1:2500 (Invitrogen Carlsbad, CA.) in $1 \times$ PBS for $1 \mathrm{~h}$ at room temperature, and washed three times in $1 \times \mathrm{PBS}$, prior to application of ImmPACT ${ }^{\mathrm{TM}}$ VIP Peroxidase Substrate Kit (Vector Laboratories) following manufacturer's instructions. To rinse and dehydrate tissue samples slides were placed consecutively into DEPC-treated water for $5 \mathrm{~min}$, and $50 \%$ ethanol and $100 \%$ ethanol for 3 min each. Slides were allowed to dry completely before application of Permaslip Mounting Medium and Liquid Coverslip Solution (American MasterTech, Lodi, CA). Immediately following the addition of mounting media, a new coverslip was applied to permanently mount and preserve the tissue sections.

\section{Microscopy}

All images were captured using a Nikon DS-Fil camera coupled with a Nikon Eclipse 80i microscope and NIS Elements imaging software (Nikon Inc., Melville, NY). The images reported here were produced through differential interference contrast (DIC) microscopy using a Nikon D-DA DIC light filter. A Nikon CFI Plan Achromat DL $10 \times$ objective lens was used to magnify samples to $100 \times$.

\section{Results and discussion}

A review of the literature showed that very few studies had been conducted using ISH to target ribosomal RNA in a fungal pathogen during active infection [20,30], several studies had targeted fungal $18 \mathrm{~S}$ rRNA for ISH $[18-24,26,30]$, and a few applied biotin-streptavidin as a reporter system $[19,37]$. We believed that the field of plant pathology could benefit from the development of a non-radioactive ISH method designed for detecting rust fungi in host plant tissue. Therefore, a baseline protocol (Fig. 1) was developed from consensus information drawn from the current literature for further testing and refinement.

\section{Sequencing for probe design}

Target sequences were required for development of probes to detect rust fungi in order to test the protocol. ISH probes for the targeted species were developed through a process of database searching, sequencing, and sequence alignment. The National Center for Biotechnology Information (NCBI) Taxonomy Browser website was used to search GenBank for 18S rRNA sequences from many fungal genera. Sequences (Table 1) were aligned in a CLUSTALW multiple sequence alignment using Biology Workbench 3.2 (http://workbench.sdsc. edu/). Sequencing primers were selected from highly conserved regions of the $18 \mathrm{~S}$ sequence for the purpose of sequencing a variable region of the 18S gDNA of two rust fungi of interest to our laboratory; Puccinia horiana and Uromyces transversalis. These primers (Table 2) amplify a $596 \mathrm{bp}$ fragment of the 18S rRNA gene. The newly obtained sequences were aligned to each of the sequences in Table 1 by pair wise local alignments, using NCBI Basic Local Alignment Search Tool (BLAST) (http://blast.ncbi.nlm.nih.gov/Blast.cgi). These alignments showed high variability when comparing rusts to non-rust fungi, but variation within rust fungi was low. From these alignments two $60 \mathrm{bp}$ regions were chosen, and upon examining the properties of their sequences using OligoCalc (http://www.basic.northwestern.edu/ biotools/oligocalc.html), a single region was selected. 


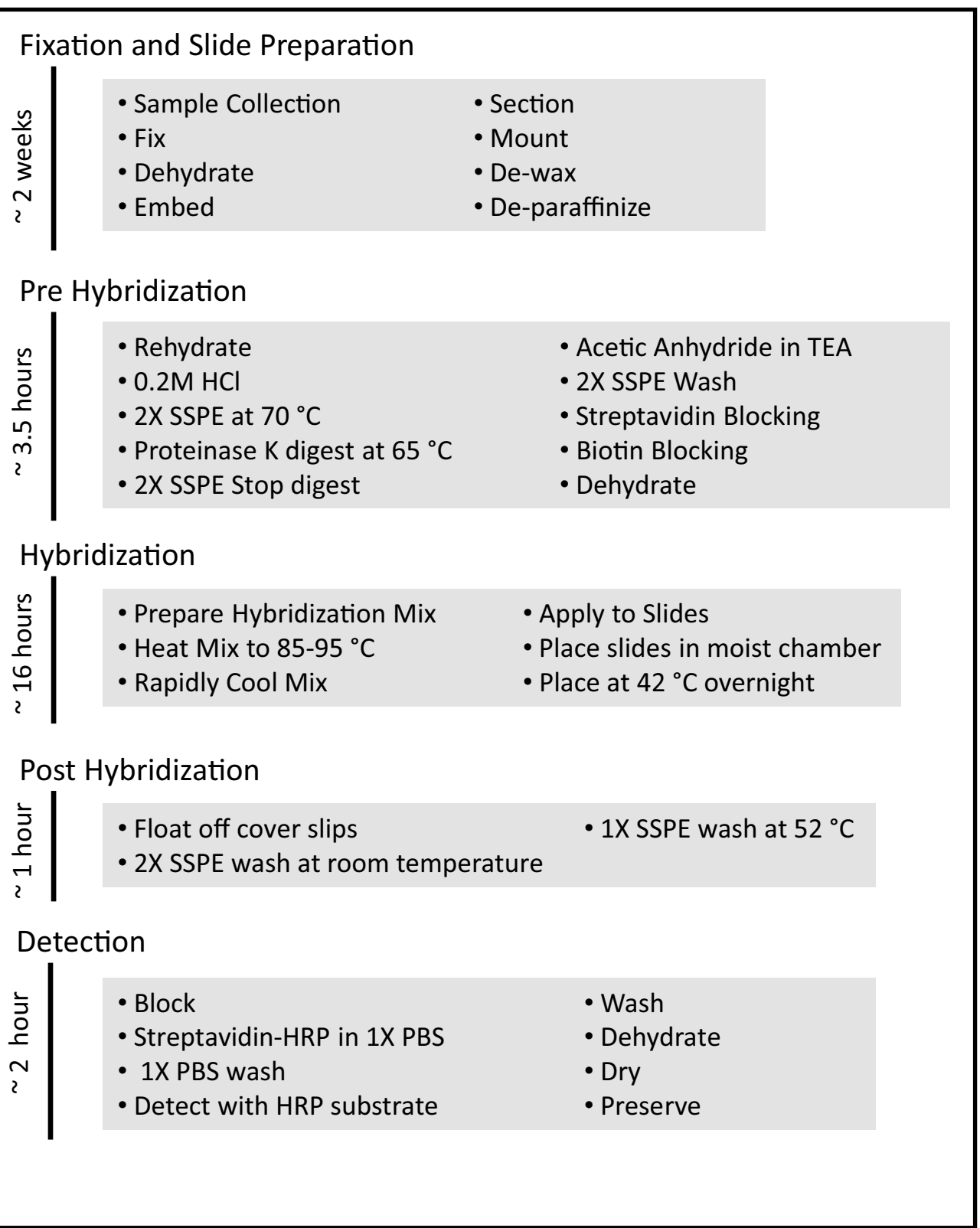

Fig. 1 Simplified list of steps included in each phase of the ISH protocol with estimated length of time spent processing samples through each phase written vertically on the left hand edge

Probes were purchased from Integrated DNA Technologies (IDT) with biotin conjugated to their 5 ' end for use ISH (probe sequences are listed in Table 2). The probes were designed to be exact matches to the 18S rRNA for their respective pathogen (Table 3 ). With precisely match probes, it was possible to refine the basic ISH protocol making modifications along the way based upon experimental results.

\section{Development of an optimized ISH protocol}

We selected a few key steps in the ISH protocol to optimize the method, using $P$. horiana-infected 
Table 1 Accession numbers of sequences used in CLUSTALW and BLAST alignments

\begin{tabular}{ll}
\hline Species & Accession \\
\hline Puccinia poarum & GenBank:DQ831029 \\
Aspergillus sojae & GenBank:D63696 \\
Aspergillus versicolor & GenBank:AB008411 \\
Eurotium herbariorum & GenBank:AB008402 \\
Cladosporium cladosporioides & GenBank:AY251093 \\
Fusarium culmorum & GenBank:AF548073 \\
Gremmeniella abietina & GenBank:AF548074 \\
Monographella nivalis & GenBank:AF064049 \\
Paecilomyces lilacinus & GenBank:AB103380 \\
Penicillium brevicompactum & GenBank:AF548083 \\
Rhizopus azygosporus & GenBank:AB250156 \\
Stachybotrys sp. & GenBank:DQ069246 \\
Trichoderma harzianum & GenBank:AF548100 \\
Alternaria botrytis & GenBank:AF548105 \\
Saccharomyces cerevisiae & GenBank:Z75578 \\
Wallemia sebi & GenBank:AF548108 \\
Phakopsora pachyrhizi & GenBank:DQ354536 \\
\hline
\end{tabular}

chrysanthemum leaves as the test material. Steps tested were proteinase $\mathrm{K}$ concentration, presumably affecting accessibility of the target RNA within the tissue, formamide concentration, which controls the strength of the hybridization process, final wash temperature, which controls the stringency of hybridization, and probe concentration. The protocol was tested both with and without a proteinase $\mathrm{K}$ digestion (for $20 \mathrm{~min}$ with $10 \mu \mathrm{g} / \mathrm{mL}$ of proteinase $\mathrm{K}$ at $65{ }^{\circ} \mathrm{C}$ ) and the results illustrated the necessity of this step, with no signal observed in the undigested samples (see Fig. 2a). Additionally, four proteinase $\mathrm{K}$ concentrations $(10,20,40$, and $80 \mu \mathrm{g} / \mathrm{mL})$ were tested to determine an optimum concentration. A concentration of $10 \mu \mathrm{g} / \mathrm{mL}$ proteinase $\mathrm{K}$ worked best to allow probe access without disturbing tissue morphology (see Fig. 2b). Next four concentrations of formamide $(10,30,50$, and $70 \%)$ were tested along with two wash temperatures (42 and $52{ }^{\circ} \mathrm{C}$ carried out in $1 \times$ SSPE for $30 \mathrm{~min}$ ). Minimal differences were observed between wash temperatures, but formamide concentrations showed large differences, with lower concentrations resulting in increased signal (see Fig. 3). The results of this experiment led to the selection of two formamide concentrations for testing (50 and $10 \%)$ with healthy plant control samples and sense probe (which should not hybridize to the target RNA sequence). Negligible background was observed in the sense-probetreated infected tissue with a $42{ }^{\circ} \mathrm{C}$ wash and no background was observed in healthy plant samples treated with either probe. The optimal signal was obtained with $10 \%$ formamide in the hybridization mix and the least background was observed with a $52{ }^{\circ} \mathrm{C}$ wash (see Fig. 4). Lastly probe concentration was varied (1,3, and $9 \mathrm{ng} /$ $\mu \mathrm{L}$ ), and increased signal was observed when using $9 \mathrm{ng} /$

\section{Table 2 List of sequencing primers and ISH probes used in this study}

\begin{tabular}{|c|c|}
\hline Primer/probe & Sequence \\
\hline Primer 1 Puccinia 18 S Forward (30 bp) & 5' CAATTGGAGGGCAAGTCTGGTGCCAGCAGC 3' \\
\hline Primer 2 Puccinia $18 \mathrm{~S}$ Reverse (30 bp) & 5'TGGACCTGGTGAGTTTCCCCGTGTTGAGTC 3' \\
\hline Puccinia horiana $18 \mathrm{~S}$ Anti-Sense & 5'/biotin/AAGTTCACCAAGAGGTAAGCCTCCAACAA ATCAGTACACACCAAAAGGCAGACCAACTGC $3^{\prime}$ \\
\hline Puccinia horiana 185 Sense & 5'/biotin/GCAGTTGGTCTGCCTTTTGGTGTGTACT GATTTGTTGGAGGCTTACCTCTTGGTGAACTT 3' \\
\hline Uromyces transversalis $18 \mathrm{~S}$ Anti-Sense & 5'/biotin/AAGTTCACCAAGAGGTAAGCCTCCAACA AATCAGTACACACCAAAAGGCGGACCAACTGC 3' \\
\hline Uromyces transversalis $18 \mathrm{~S}$ Sense & 5'/biotin/GCAGTTGGTCCGCCTTTTGGTGTGTACT GATTTGTTGGAGGCTTACCTCTTGGTGAACTT 3' \\
\hline Phakopsora pachyrhizi 18 S Anti-Sense & 5'/biotin/AGGTTCACCAAGAGGTAAGCCTCCAAC AAATCAGTACACACCAAATGGCGGACCAACTGC $3^{\prime}$ \\
\hline Phakopsora pachyrhizi 185 Sense & 5'/biotin/GCAGTTGGTCCGCCATTTGGTGTGTACT GATTTGTTGGAGGCTTACCTCTTGGTGAACCT 3' \\
\hline
\end{tabular}

Table 3 CLUSTALW alignment of anti-sense probes

\begin{tabular}{ll}
\hline Species & Sequence \\
\hline Uromyces transversalis & AAGTTCACCAAGAGGTAAGCCTCCAACAAATCAGTACACACCAAAAGGCGGACCAACTGC \\
Puccinia horiana & AAGTTCACCAAGAGGTAAGCCTCCAACAAATCAGTACACACCAAAAGGCAGACCAACTGC \\
Phakopsora pachyrhizi & AGGTTCACCAAGAGGTAAGCCTCCAACAAATCAGTACACACCAAATGGCGGACCAACTGC \\
& $* * * * * * * * * * * * * * * * * * * * * * * * * * * * * * * * * * * * * * * * * * * * * * * * *$
\end{tabular}




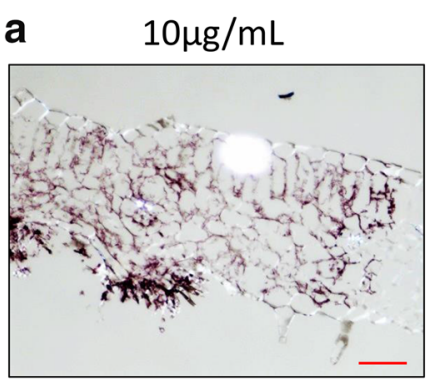

No digestion

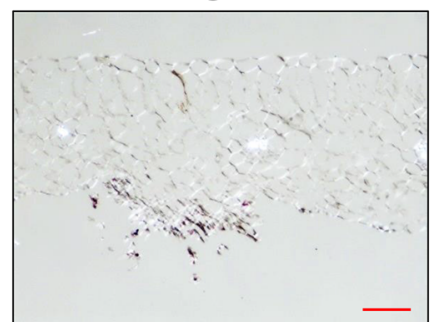

Fig. 2 Images of samples of C. $\times$ morifolium infected with P. horiana prepared by ISH (Red scale bar $=100$ um). a Samples processed with (top) and without (bottom) a proteinase K digestion. b Samples processed using four different proteinase K concentrations. Purple staining of the tissue indicates hybridization signal generated by HRP reacting with purple substrate

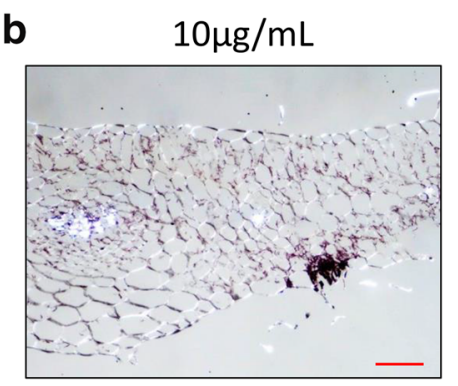

$40 \mu \mathrm{g} / \mathrm{mL}$
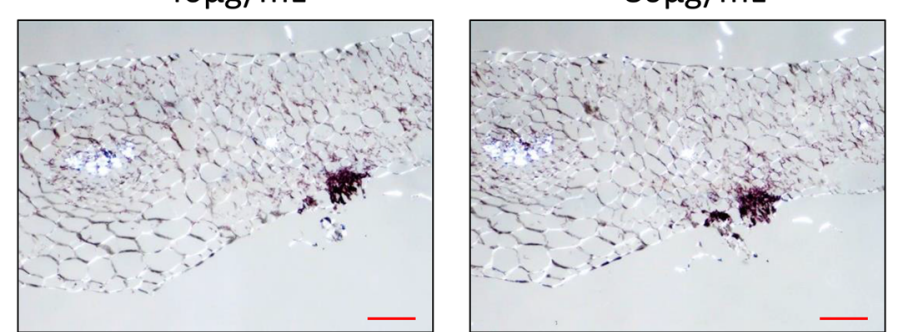

$\mu \mathrm{L}$ with no additional background. These empirically determined conditions discovered as the result of these experiments were incorporated into a final optimized protocol. The protocol had, at this point, only been tested using sections of Chrysanthemum $\times$ morifolium infected with Puccinia horiana and further testing was required to determine the generality and reproducibility of the protocol.

\section{Application of the protocol to rust fungi}

In order to validate the applicability and reproducibility of the refined protocol, samples were taken from two other research subjects in our laboratory; Gladiolus $\times$ hortulanus infected with $U$. transversalis and Glycine max infected with P. pachyrhizi. Slides containing samples of both pathogens were treated with both sense and anti-sense probes using the optimized protocol. These experiments demonstrated that the refined ISH protocol is effective on species within the genera Puccinia (Figs. 2, 3, 4) Uromyces and Phakopsora (Figs. 5, 6). When applied to Glycine max infected with P. pachyrhizi, the signal was weak compared to the other two species (Fig. 6). U. transversalis samples showed strong signal in all slides prepared with the anti-sense probe and no signal in the infected tissue prepared with the sense probe. Healthy plant tissue processed with both sense and anti-sense probes showed no signal, demonstrating further that this technique is preferentially staining pathogen tissue and not the host plant. The strength of signal obtained from $U$. transversalis samples was equivalent to signal observed in $P$. horiana samples. P. pachyrhizi showed weak signal in one out of five slides prepared with anti-sense probe and the other four appear the same as slides treated with the sense probe. The fact that some signal was observed indicates that this technique requires further optimization for $P$. 


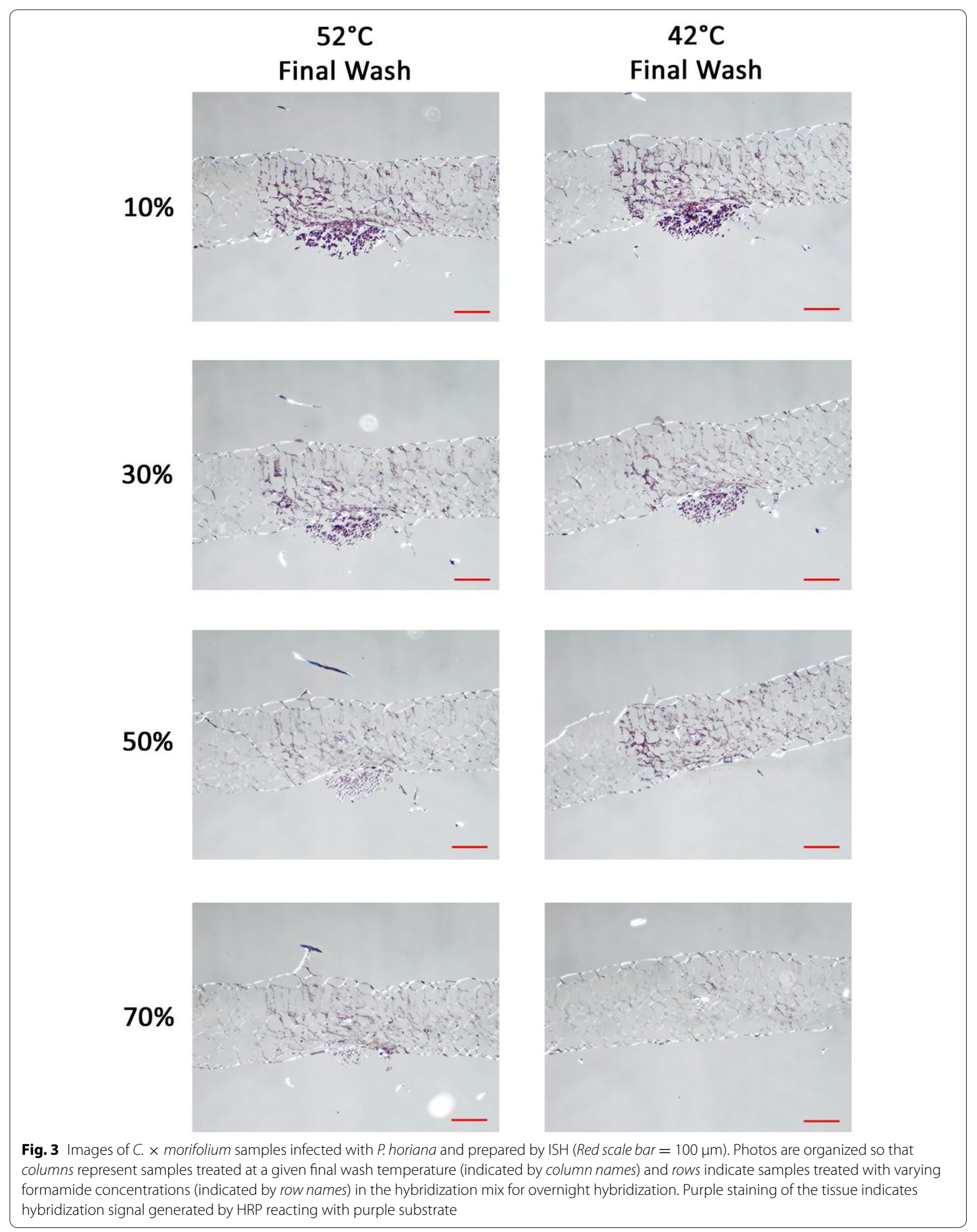




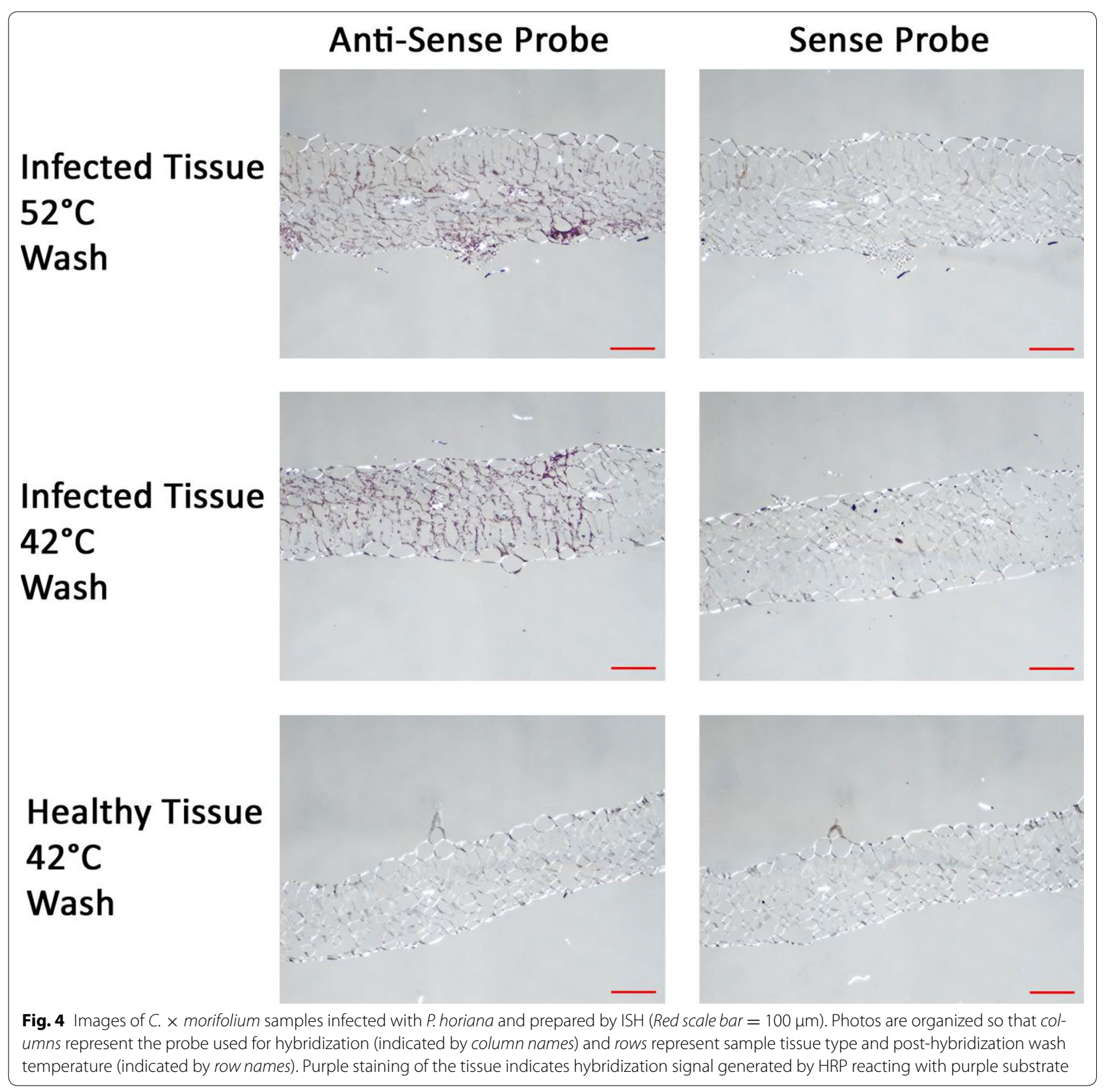

pachyrhizi. In particular the alteration of the high temperature steps could potentially increase signal strength by reducing sample loss.
The images presented here are at relatively low magnification, and resolution is therefore at the tissue level. Further magnification of images did not resolve at the 


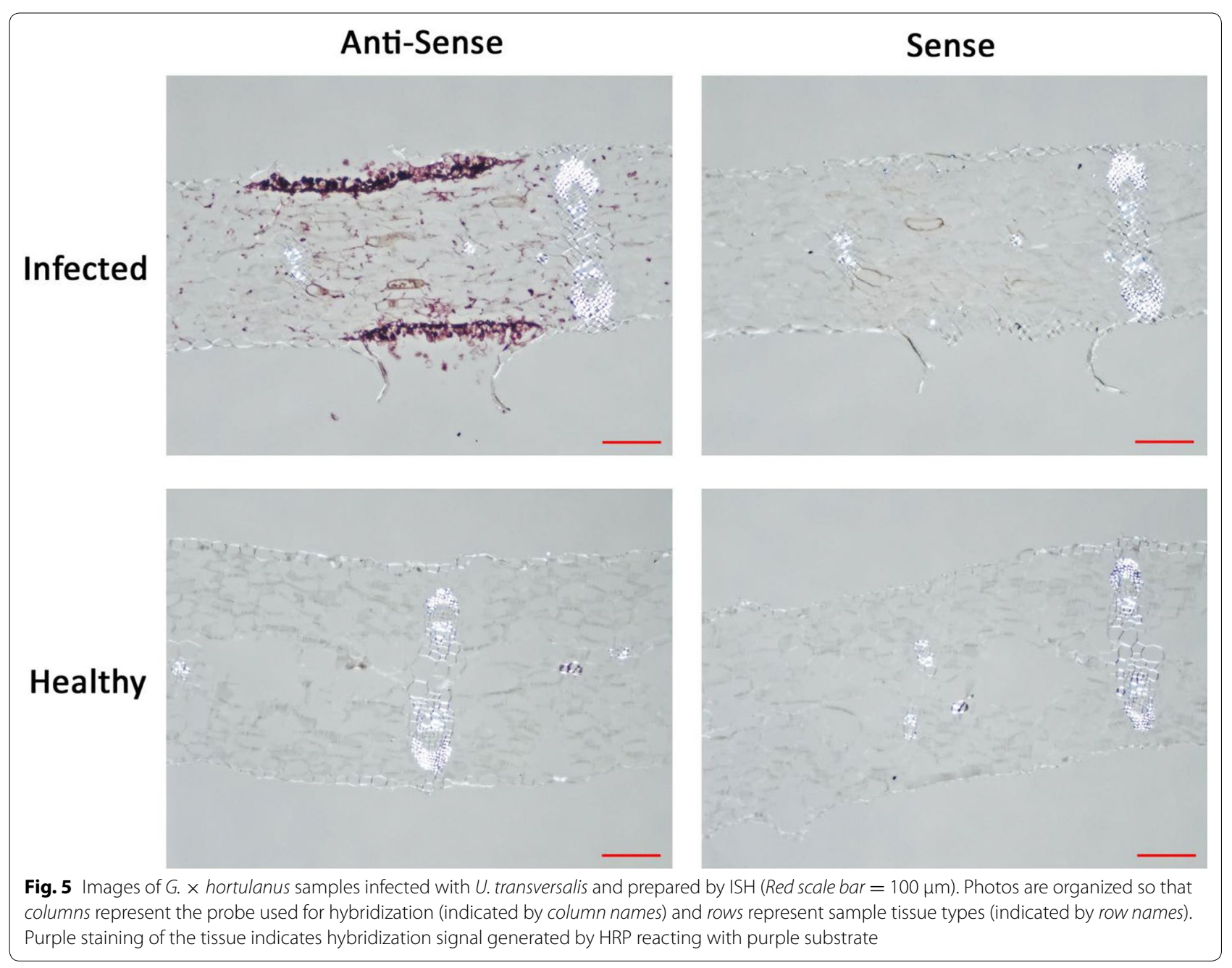

intracellular level (not shown). Use of a fluorescent label rather than precipitable stain may result in higher-level resolution.

\section{Conclusion}

We present here a generalized ISH protocol for localization of rust fungi in paraffin embedded sections of host tissues. This technique provides plant pathologists with a tool to study the morphology of rust fungi within the plants they infect, which may aid in the elucidation of the life cycles of these plant pathogenic fungi and determination of fungal growth patterns in host tissue. We have demonstrated that this protocol can be applied to pathogens from different genera of rust fungi residing in different plant hosts with little to no non-specific background staining of plant tissue. Our protocol is easy to apply and 


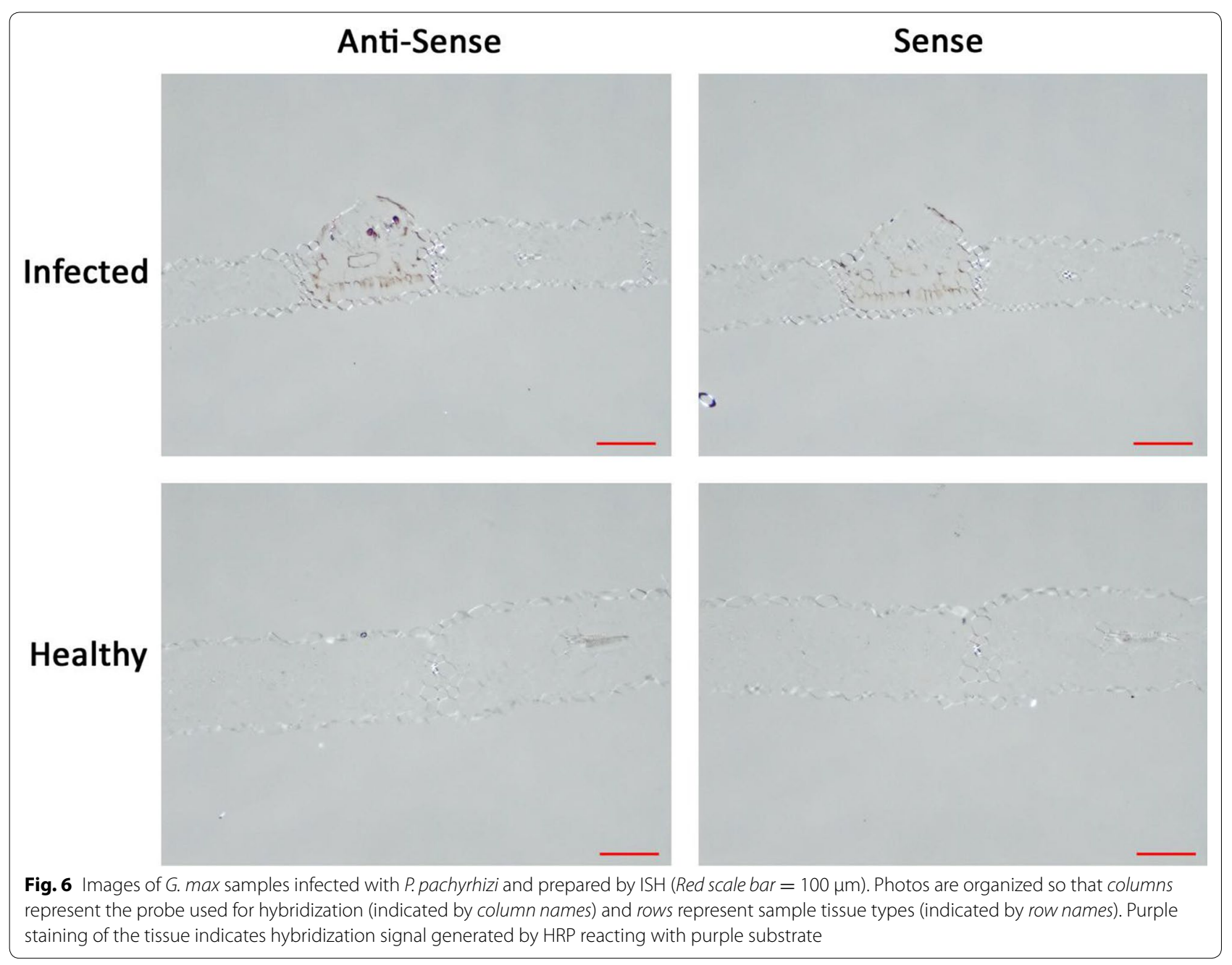

modify if necessary. The generic protocol thus serves as a starting point that may be modified to suit other plant pathogen systems of interest.

\section{Authors' contributions}

MAE co-conceived the project, adapted methods, conducted the experiments, tested protocols and wrote the manuscript, MBM co-conceived the project, provided guidance, improvements and reagents, and edited the manuscript, MRB and CLP edited the manuscript, DGL co-conceived the project and edited the manuscript. All authors read and approved the final manuscript.

\section{Author details}

${ }^{1}$ Department of Biology, University of Pittsburgh School of Medicine, Pittsburgh, PA, USA. ${ }^{2}$ USDA-ARS Foreign Disease-Weed Science Research Unit, Ft. Detrick, MD, USA. ${ }^{3}$ IR-4 Project, Rutgers University, Princeton, NJ, USA.

\section{Acknowledgements}

The authors thank Dr. Kerry Pedley and Amy Ruck for providing U. transversalis spore DNA and P. pachyrhizi infected soybean samples, Dr. Reid Frederick for advice and healthy soybean tissue, and Susan Nester for providing $P$. horiana - infected Chrysanthemum tissue and U. transversalis_-infected Gladiolus tissue. MAE wishes to thank Dr. Oney P. Smith, Hood College, for many stimulating ideas and discussions.

\section{Competing interests}

The authors declare that they have no competing interests.

\section{Commercial endorsement disclaimer}

The use of trade, firm, or corporation names on this page is for the information and convenience of the reader. Such use does not constitute an official endorsement of approval by the USDA Agricultural Research Service, NAL or $\mathrm{BIC}$ of any product or service to the exclusion of others that may be suitable.

\section{Equal opportunity statement}

USDA is an equal opportunity provider and employer.

\section{Funding}

This work was supported by USDA, ARS and by USDA APHIS Farm Bill 10007 research grants coordinated by author Dr. Cristi L. Palmer, IR-4 Project, Rutgers University.

Received: 22 April 2016 Accepted: 19 July 2016

Published online: 27 July 2016

\section{References}

1. Dean R, Van Kan JA, Pretorius ZA, Hammond-Kosack KE, Di Pietro A, Spanu PD, Rudd JJ, Dickman M, Kahmann R, Ellis J, et al. The Top 10 fungal pathogens in molecular plant pathology. Mol Plant Pathol. 2012;13:414-30.

2. Yamaoka Y. Recent outbreaks of rust diseases and the importance of basic biological research for controlling rusts. J Gen Plant Pathol. 2014:80:375-88. 
3. Bromfield KR. Soybean Rust (Monograph). St. Paul: APS Press; 1984.

4. Schneider RW, Hollier CA, Whitam HK. First report of soybean rust caused by Phakopsora pachyrhizi in the continental United States. Plant Dis. 2005:89:774.

5. Gall JG, Pardue ML. Nucleic acid hybridization in cytological preparations. Methods Enzymol. 1971;21:470-80.

6. Zeller R, Rogers M, Haramis AG. In situ hybridization to cellular RNA. Curr Protoc Mol Biol. 2001:14.13. 11-14.13. 16.

7. Brahic M, Haase AT. Detection of viral sequences of low reiteration frequency by in situ hybridization. Proc Natl Acad Sci USA. 1978;75:6125-9.

8. Haramis A, Carrasco A. Whole-mount in situ hybridization and detection of RNAs in vertebrate embryos and isolated organs. Curr Protoc Mol Biol. 1996:14.19.

9. Lawrence JB, Singer RH. Quantitative analysis of in situ hybridization methods for the detection of actin gene expression. Nucleic Acids Res. 1985;13:1777-99.

10. Singer $R$, Lawrence JB, Villnave $C$. Optimization of in situ hybridization using isotopic and nonisotopic detection methods. Biotechniques. 1986;4:230-50.

11. Singer RH, Ward DC. Actin gene expression visualized in chicken muscle tissue culture by using in situ hybridization with a biotinated nucleotide analog. Proc Natl Acad Sci USA. 1982;79:7331-5.

12. Landegent J, De Wal NJI, Baan R, Hoeijmakers J, Van der Ploeg M. 2-Acetylaminofluorene-modified probes for the indirect hybridocytochemical detection of specific nucleic acid sequences. Exp Cell Res. 1984;153:61-72

13. Pinkel D, Landegent J, Collins C, Fuscoe J, Segraves R, Lucas J, Gray J. Fluorescence in situ hybridization with human chromosome-specific libraries: detection of trisomy 21 and translocations of chromosome 4. Proc Natl Acad Sci USA. 1988;85:9138-42.

14. Pinkel D, Straume T, Gray J. Cytogenetic analysis using quantitative, high-sensitivity, fluorescence hybridization. Proc Natl Acad Sci USA. 1986:83:2934-8

15. Brandriff B, Gordon L, Fertitta A, Olsen A, Christensen M, Ashworth L, Nelson D, Carrano A, Mohrenweiser H. Human chromosome 19p: a fluorescence in situ hybridization map with genomic distance estimates for 79 intervals spanning 20 Mb. Genomics. 1994;23:582-91.

16. Gordon L, Bergmann A, Christensen M, Danganan L, Lee D, Ashworth L, Nelson D, Olsen A, Mohrenweiser H, Carrano A. A 30-Mb metric fluorescence in situ hybridization map of human chromosome 19q. Genomics. 1995;30:187-92.

17. Assmus B, Hutzler P, Kirchhof G, Amann R, Lawrence JR, Hartmann A. In situ localization of azospirillum brasilense in the rhizosphere of wheat with fluorescently labeled, rRNA-targeted oligonucleotide probes and scanning confocal laser microscopy. Appl Environ Microbiol. 1995:61:1013-9.

18. Glöckner FO, Amann R, Alfreider A, Pernthaler J, Psenner R, Trebesius K, Schleifer K-H. An in situ hybridization protocol for detection and identification of planktonic bacteria. Syst Appl Microbiol. 1996;19:403-6.

19. Li AY, Crone M, Adams PJ, Fenwick SG, Hardy GE, Williams N. The microscopic examination of Phytophthora in plant tissues using fluorescent in situ hybridization. J Phytopathol. 2014;162:747-57.

20. Montone KT, Guarner J. In situ hybridization for rRNA sequences in anatomic pathology specimens, applications for fungal pathogen detection: a review. Adv Anat Pathol. 2013;20:168-74.
21. Montone KT, LiVolsi VA, Lanza DC, Kennedy DW, Palmer J, Chiu AG, Feldman MD, Loevner LA, Nachamkin I. In situ hybridization for specific fungal organisms in acute invasive fungal rhinosinusitis. Am J Clin Pathol. 2011;135:190-9.

22. Schröder S, Hain M, Sterflinger K. Colorimetric in situ hybridization (CISH) with digoxigenin-labeled oligonucleotide probes in autofluorescent hyphomycetes. Int Microbiol. 2010;3:183-6.

23. Shinozaki M, Okubo Y, Sasai D, Nakayama H, Ishiwatari T, Murayama S, Tochigi N, Wakayama M, Nemoto T, Shibuya K. Development and evaluation of nucleic acid-based techniques for an auxiliary diagnosis of invasive fungal infections in formalin-fixed and paraffin-embedded (FFPE) tissues. Med Mycol. 2012;53:241-5.

24. Sterflinger K, Hain M. In situ hybridization with rRNA targeted probes as a new tool for the detection of black yeasts and meristematic fungi. Stud Mycol. 1999:43:23-30

25. Tanaka E. Specific in situ visualization of the pathogenic endophytic fungus Aciculosporium take, the cause of witches' broom in bamboo. Appl Environ Microbiol. 2009:75:4829-34.

26. Vági P, Knapp DG, Kósa A, Seress D, Horváth ÁN, Kovács GM. Simultaneous specific in planta visualization of root-colonizing fungi using fluorescence in situ hybridization (FISH). Mycorrhiza. 2014;24:259-66.

27. Amann R, Fuchs BM, Behrens $S$. The identification of microorganisms by fluorescence in situ hybridisation. Curr Opin Biotechnol. 2001;12:231-6.

28. Bloch B. Biotinylated probes for in situ hybridization histochemistry: use for mRNA detection. J Histochem Cytochem. 1993;41:1751-4.

29. Brigati DJ, Myerson D, Leary JJ, Spalholz B, Travis SZ, Fong CK, Hsiung $G$, Ward DC. Detection of viral genomes in cultured cells and paraffinembedded tissue sections using biotin-labeled hybridization probes. Virology. 1983;126:32-50.

30. Moter A, Göbel UB. Fluorescence in situ hybridization (FISH) for direct visualization of microorganisms. J Microbiol Methods. 2000;41:85-112.

31. Wagner M, Horn M, Daims H. Fluorescence in situ hybridisation for the identification and characterisation of prokaryotes. Curr Opin Microbiol. 2003;6:302-9.

32. Zachgo S. In situ hybridization. In: Gilmartin PM, Bowler C, editors. Molecular plant biology. 2nd ed. New York: Oxford University Press; 2002. p. 41-63.

33. Bonde MR, Palmer CL, Luster DG, Nester SE, Revell JM, Berner DK. Sporulation capacity and longevity of Puccinia horiana teliospores in infected chrysanthemum leaves. Plant Health Prog. 2013. doi:10.1094/ PHP-2013-0823-01-RS.

34. Bonde MR, Nester SE, Luster DG, Palmer CL. Longevity of Uromyces transversalis, causal agent of gladiolus rust, under various environmental conditions. Plant Health Prog. 2015. doi:10.1094/PHP-RS-14-0036.

35. Lamour KH, Finley L, Snover-Clift KL, Stack JP, Pierzynski J, Hammerschmidt R, Jacobs JL, Byrne JM, Harmon PF, Vitoreli AM, et al. Early detection of Asian soybean rust using PCR. Plant Health Prog. 2006. doi:10.1094/PHP-2006-0524-01-RS.

36. Denhardt DT. A membrane-filter technique for the detection of complementary DNA. Biochem Biophys Res Commun. 1966;23:641-6.

37. McManus J, Cason JE. Carbohydrate histochemistry studied by acetylation techniques: I. Periodic acid methods. J Exp Med. 1950;91:651.

\section{Submit your next manuscript to BioMed Central and we will help you at every step:}

- We accept pre-submission inquiries

- Our selector tool helps you to find the most relevant journal

- We provide round the clock customer support

- Convenient online submission

- Thorough peer review

- Inclusion in PubMed and all major indexing services

- Maximum visibility for your research

Submit your manuscript at www.biomedcentral.com/submit 